\title{
Saying yes to the precautionary principle
}

\author{
Review by D arcy Mullen * \\ G eorgia Institute of Technology
}

Review of A Precautionary Tale: $\mathrm{H}$ ow $\mathrm{O}$ ne Small T own Banned Pesticides, Preserved its F ood $\mathrm{H}$ eritage, and Inspired a M ovement, by Philip Ackerman-Leist. (2017). Published by Chelsea G reen Publishing. Available as hardcover, paperback, and ebook; 280 pages. Publisher's website: https:/ / www.chelseagreen. $\mathrm{com} /$ product/ a-precautionary-tale/

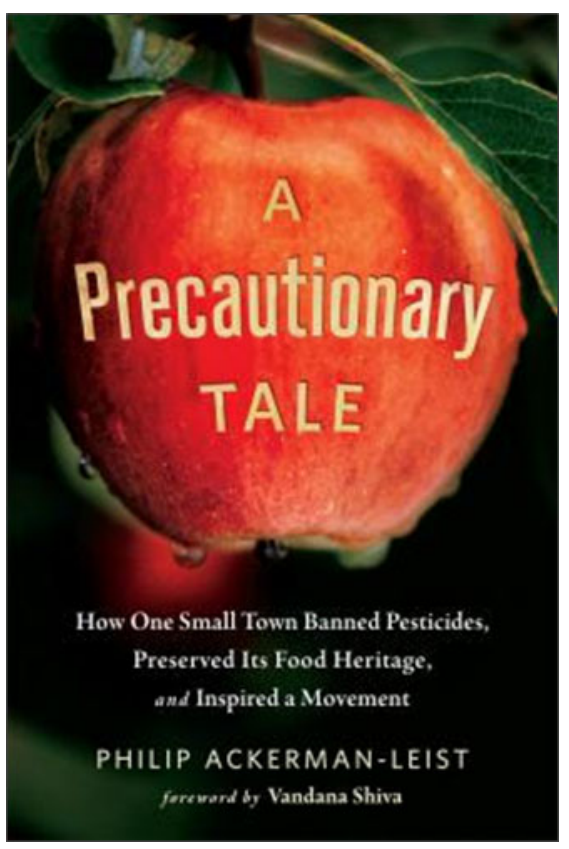

Submitted January 31, 2018 / Published online June 7, 2018

Citation: Mullen, D . (2018). Saying yes to the precautionary principle [Book review]. Journal of A griculture, Food Systems, and C ommunity D evelopment, 8(2), 157-159. https:/ / doi.org/ 10.5304/ jafscd.2018.082.004

Copyright @ 2018 by the Author. Published by the Lyson Center for Civic Agriculture and Food Systems. Open access under CC BY license.

$\mathrm{I}_{\mathrm{B}}^{\mathrm{n}}$ n A Precautionary Tale: H ow 0 ne Small T own Banned Pesticides, Preserved Its F ood $\mathrm{H}$ eritage, and Inspired a M ovement, Philip Ackerman-Leist tells the story of Mals, in Northern Italy. He does it in a way that makes the reader feel as if they have

* D arcy Mullen, School of Literature Media and Communication, Ivan Allen College of Liberal Arts; G eorgia Tech; 686 Cherry Street; Atlanta, G eorgia 30332-0165 USA; darcy.mullen@lmc.gatech.edu

D arcy Mullen, Ph.D ., is a 2017 Postdoctoral Marrion L. Brittain Fellow at Georgia Institute of Technology. Mullen received her $\mathrm{PhD}$ at the University at Albany, with a strong interdisciplinary focus on the Rhetoric of Food, and Social Movement Studies. Her current book project, The Food and D rink of Atlanta, is forthcoming with Rowman and Littlefield's "Big Food Cities Biography" series. visited a very special place and an equally singular moment in time. Just as notably, this biography of place holds a steady eye to turns in elegant language. The title explains what happens in the book. The combination of the humanistic details and how the story is told, however, makes for a contemporary socio-agricultural fairy-tale (if such a genre can exist), complete with a supplemental chapter at the end of the book called "An Activist's Primer: How To Push Back on Pesticides At Home" (pp. 195-199).

Snapshots from the book could be easily confused with contemporary literature or prose. The last chapter ("Ja!"), the end of the story, concludes with the aphoristic, "sometimes the future is dependent upon what we save from the 
past, and sometimes it's more about what we decide to leave behind" (p. 192). This sentence is reminiscent of writings from authors like the award-winning Kazuo Ishiguro, the most recent Nobel Prize winner in literature. Ishiguro won the prize for writing that " ... has uncovered the abyss beneath our illusory sense of connection with the world" (Nobelprize.org, n.d., para. 1). It is not hyperbolic to argue that Ackerman-Leist has used the case study of Mals to tell a story about our connection with the world, and the problems (ecological and political) that ensue when those connections seem so illusory that they slip into an abyss beyond our control.

In chapter 11, "Manifesto," we get a clear outline of the legal and philosophical underpinnings that Mals both fought against and worked to preserve. In the foreword by Vandana Shiva we first see the fundamental point of the manifesto: "our right to be free from harm" (p. ix). Throughout history, these ideological foundations, when created in good faith, have provided an ethos to help us navigate the illusory sense of connection we may feel with the world. The manifesto starts with "Primum non nocere: First, do no harm," bringing us into the discourse of modern medicine (p. 154). From there it moves to a recognition "that the principles of regenerative agriculture and holistic medicine were parallel in philosophy and approach" (p. 154).

Next, we get the full manifesto created by scientists and activists in Mals. The "premise" section of the manifesto concludes with the following: "The age-old principle of law must apply to all: The freedom of the individual is limited by the rights of our neighbors'” (p. 155). Ackerman-Leist further explains that the manifesto was intended to address the problem, in our sense, of "crop protection" - that it "had somehow taken priority over the protection of humans and their environment" (p. 156). He bridges $18^{\text {th }}$ century European philosophy (Kant's M etaphysics of Morals) with the contemporary concept of "the precautionary principle" (pp. 156-161). In other words, this puts the onus for "proof for safety upon those who create or manufacture elements of risk" (p. 156), not on citizens. This is a highly anti-neoliberal principle that is at odds with the politics of blame- the-consumer in our food system. Mals' resistance, then, is not just a matter of maintaining healthy and safe connections between humans and the environment. It is the blueprint for resisting neoliberal regulations that seek to encourage disconnection from our environment.

Toward the end of chapter two, "Roots of a Rebellion," I found myself Googling, printing, and annotating a map to try to figure out the geographic intersections of Mals. My familiarity with the geography of Northern Italy is minimal. The absence of a map orienting the reader with very tiny towns in Northern Italy, and surrounding towns and landmarks, unfortunately distracted from the reading while I was generating a map for myself.

In the end-matter of the book, we see the full possibilities of this book as a metatextual project, with its companion website. ${ }^{1}$ At the time that I first read the book, the website was still under construction. Ackerman-Leist emphasizes that the story of Mals' resistance relies on visual rhetoric that I very much wanted to see. For example, in the chapter "Bufferless," we get the following description of agricultural scope: "with an average of thirty pesticide sprayings per year in those orchards, it's not just the apples that are spreading. It's hard to picture what it looks like. Until you photograph it, that is" (p. 43). I was salivating for a photograph, because he is right-it is hard to picture what this looks like. I felt this often, wanting to see an image of the "'resistance sunflowers" (p. 171), or one of the bedsheets that had been turned into a protest banner that was the subject of chapter 10 (pp. 141, 149-151).

The companion website delivered on the multimodal possibilities with this book and its larger project. It offers the visuals and extratextual materials that show the importance of visual communication in this movement. Moreover, this rich website would make this book an excellent addition to a higher-education classroom.

The thing I keep returning to from this book is the value Malsers put on the logic of aesthetics in their rhetoric of resistance. Early on, the resistance adopted a strategy of "yes" vs. "anti" in order to

\footnotetext{
1 http:// www.topplinggoliath.org/
} 
Journal of Agriculture, Food Systems, and Community Development ISSN: 2152-0801 online

https:/ / www.foodsystemsjournal.org

"focus on what you want, not what you oppose" (p. 149). That is, it called to promote health rather than oppose sickness. Rhetoric alone is not what made this movement successful, but it is an element that cannot be ignored. The last sentence of the book declares, "It's hard to say no to yes" (p. 199). This rhetoric for resistance surely is not a one-size-fitsall approach. As we work in our different communities to build sustainable and valuable connections between ourselves and our environment, it is worth examining the rhetoric of our resistance, and ask where we may have opportunities for "yes."

\section{Reference}

Nobelprize.org. (n.d.). The N obel Prize in L iterature 2017: Kazuo Ishiguro. Retrieved April 20, 2018, from https:/ / www.nobelprize.org/ nobel prizes/ literature/ laureates/2017/ 